\title{
FACTORS AFFECTING THE TIMELINESS OF FINANCIAL STATEMENT SUBMISSION
}

\author{
Stephanie Tanulia \\ Maria Stefani Osesoga* \\ Universitas Multimedia Nusantara, Jl. Scientia Boulevard, Tangerang, Indonesia \\ *maria.stefani@umn.ac.id
}

\author{
ARTICLE INFO \\ Article history: \\ Received February 4, 2021 \\ Revised May 10, 2021 \\ Accepted July 11, 2021
}

Key words:

Audit; DER; Firm Size; Structure; Timeliness

DOI:

https://doi.org/10.33508/jako.v14i1.3022

\begin{abstract}
Research Purposes. This study aims to determine the effect of DER (debt to equity ratio), audit delay, public ownership structure, firm size, and auditor switching on the timeliness of financial statement submission. It is important in maintaining the relevance of information in financial statements because a relevant information can help users in making decision.

Research Methods. Secondary data with a purposive sampling method was used in selecting samples and analyzed using logistic regression methods. There were 39 consumer goods companies used as samples after qualified the sample selection criteria.

Research Result and Findings. The results conclude that DER, audit delay, and public ownership structure have a significant negative effect on timeliness of financial statements submission, firm size has a significant positive effect on the timeliness of financial statements submission, and auditor switching has no effect on the timeliness of financial statement submission.
\end{abstract}

\begin{abstract}
ABSTRAK
Tujuan Penelitian. Penelitian ini menguji pengaruh DER (debt to equity ratio), audit delay, struktur kepemilikan publik, ukuran perusahaan, dan pergantian auditor terhadap ketepatan waktu penyampaian laporan keuangan. Ketepatan waktu penyampaian laporan keuangan menjadi hal yang penting dalam menjaga relevansi informasi dalam laporan keuangan karena dapat mempengaruhi pengambilan keputusan.

Metode Penelitian. Data sekunder dengan menggunakan metode purposive sampling digunakan dalam penelitian ini dan dianalisa dengan metode regresi logistik. Terdapat 39 perusahaan barang konsumsi yang digunakan sebagai sampel setelah memenuhi kriteria pemilihan sampel.

Hasil dan Temuan Penelitian. Hasil pengujian menunjukkan bahwa DER, audit delay, dan struktur kepemilikan publik berpengaruh negatif signifikan terhadap ketepatan waktu penyampaian laporan keuangan, sedangkan ukuran perusahaan berpengaruh positif signifikan terhadap ketepatan waktu penyampaian laporan keuangan, dan pergantian auditor tidak berpengaruh negatif terhadap ketepatan waktu penyampaian laporan keuangan.
\end{abstract}

\section{INTRODUCTION}

The objective of financial statements is providing information about entity's financial position, financial performance, and cash flow which is useful for users of financial statements to make decisions and also to indicate the results of management's accountability. The financial statements information must meet two qualitative characteristics: fundamental and enhancing qualitative characteristics. Fundamental qualitative characteristics consist of relevance and precise representation while enhancing fundamental qualitative characteristics consist comparability, verifiability, timeliness, and understandability (Ikatan Akuntan Indonesia,
2018). One of the problems that often arise regarding the relevance and timeliness of financial statements is delays in the submission of financial statements.

The timeliness of financial statements submission is important because it will have an impact on the decision making of the financial statements' users. If the company submits its financial statements on time, the reliability and relevance of the information in its financial statements will be maintained, and conversely, if the company is late in submitting its financial statements, the reliability and relevance of the information in its financial statements will be reduced. 
Timeliness means the availability of information for decision makers at the right time so that it can influence their decisions (Ikatan Akuntan Indonesia, 2018). To ensure that companies are timely in submitting their financial reports, the Otoritas Jasa Keuangan (2011) in the Surat Keputusan (SK) Bapepam No. KEP-346/BL/2011 attachment No. X.K.2 and Peraturan Bursa Efek Indonesia (2004) No. III.1.6.2. regulates the obligation to submit public company financial statements, not later than the end of the 3rd (third) month after the date of the annual financial statements. In March 2020, OJK and Indonesia Stock Exchange (IDX) issued provisions related to anticipation of the Covid-19 pandemic on Press Release and IDX Decree No. Kep-00027/BEI/03-2020 regarding relaxation of the deadline which stated that the 2019 annual report submission is extended for 2 (two) months from the predetermined time limit (Bursa Efek Indonesia, 2020).

Although financial statements are important instruments for public companies, there are companies late in submitting their financial statements. From the 2017 to 2019 period, the number of companies that were late in submitting their financial statements fluctuated, even though it had experienced a decline from year 2017 to 2018, from 20 companies to 13 companies. In the 2019 period, companies that were late in submitting their financial reports more than doubled to 30 , even though the regulators had given leeway time to submit their financial statements to May 31st, 2020 (Bursa Efek Indonesia, 2020).

The timeliness of financial statements submission referred to the availability of audited financial statement information for decision makers at the latest at the end of the third month after the date of the financial statements so that it can influence their decisions. The timeliness of financial statements submission is important because it can influence the decision making of its users. Investors need information related to the rate of return on investment made, such as information about the company's profits. High profit indicates the level of return that will be provided by the company and will attract investors to invest in the company. Meanwhile, creditors need information about the company's credit risk, such as information related to company liabilities. If the company's liabilities are low, creditors will tend to be interested in providing credit because it means that the risk of the company failing to pay off its obligations is also low.
One of the consumer goods sector companies that were late and subject to suspension sanctions was PT Tiga Pilar Sejahtera Foods Tbk. (AISA). Suspension has been received by AISA since July $5^{\text {th }}, 2018$. This has occurred because AISA has not submitted its financial reports from 2017 to 2018. In 2017 , the former management clashed with the new management due to allegations of financial statement manipulation. Which made AISA's board of commissioners reluctant to sign AISA's 2017 financial statements due to the absence of precise explanations related to several transactions that occurred in the 2017 financial statements (Forddanta and Rafie, 2018). On 22 October 2018, AISA held RUPS which inaugurated new board of directors and commissioners and mandated new management to conduct investigative audits of several accounts in the financial statements of TPS Food (Saragih, 2019).

Under the new management, AISA is still unable to submit its financial reports, due to obstacles in the transition from former management to new management which is considered not proper. The obstacles also relate to data access, financial reports, and other financial data belonging to the company which will be used to prepare the 2017 report restatement and the 2018 annual financial report (Saleh, 2019). The delay in submitting this financial report makes the company subject to suspension due to not being able to meet the fine and not immediately reporting its financial report, and the suspension must be continued because the company gets a disclaimer opinion on the 2017 and 2018 financial statements from the public accounting firm EY. The chaos that occurred in AISA's management prompted OJK to ask the company to report back its 2017 financial statements. However, the company has just submitted a restated 2017 financial report, audited 2018 financial report, and 2019 first semester financial report on 11 February 2020 (Thertina, 2020).

Previous research about timeliness of financial statements verified that many factors could affect it. Ferdina and Wirama (2017) stated that profitability, leverage, and firm size affect timeliness. Sanjaya and Wirawati (2016) proved that firm size, auditor switching, structure of ownership, profitability, and debt to equity ratio have significant effect on timeliness financial statements. Study by Rahmayanti (2016) concluded that audit delay and profitability affect timeliness. Mukhtar, Sebrina and Mulyani (2019) stated that timeliness of financial statements is affected by leverage, auditor switching, and 
number of audit committee. That research gap encourages researcher to investigate factors that affect the timeliness of financial statements submission, namely debt to equity ratio (DER), audit delay, ownership structure, company size, and auditor change.

Debt to Equity Ratio or DER is used to measure the level of debt against the total equity owned by the company. DER is calculated by comparing total liabilities to total equity. If the DER of a company is low, it indicates that the use of debt as a financial source is low so that financial risks and the possibility of default will be lower. This is good news for investors as well as creditors so that the company will try to be on time in submitting its financial statements to auditors. If the company submits its financial statements to the auditors faster and also provide information related to the evidence of corporate financial risk required by the auditors, the auditors will complete the audit process and the audit report more quickly, so that companies can be on time in submitting their audited financial statements to the public. Research by Pradipta and Suryono (2017); Ferdina and Wirama (2017); Janrosi and Prima (2016) show that the debt to equity ratio (DER) has a significant effect on the timeliness of financial statement submission. However, Elviani (2017); Utami and Yennisa (2017); Soares and Amin (2016) state that DER has no significant effect on the timeliness of financial statement submission.

Audit delay is the time span required by a public accountant to complete the auditing process to present his opinion on the annual financial report (Soares and Amin, 2016). If the company is willing to provide information related to the evidence needed by the auditors during the audit process, the audit delay will be shorter. Due to the availability of the company in providing information related to the evidence needed by the auditor, it can speed up the audit process carried out by the auditor. This makes the time needed for companies to get their audited financial reports faster, so the company will be faster (on time) in submitting their audited financial statements to the public. Previous researches conducted by Soares and Amin (2016); Ningsih (2016) state that audit delay has a significant effect on the timeliness of submitting financial statements. On the contrary, Astuty (2016) proved that audit delay does not have a significant effect on the timeliness of submitting financial statements.

Public ownership structure is the proportion of shares owned by the public to company shares (be- low 5\%) (Hamdani, Yuliandari and Budiono, 2017). The public ownership structure is calculated by comparing the number of public shareholdings with the number of outstanding shares of the company. The higher the public ownership structure, the more shares of the company are owned by the public. This makes companies have to maintain their credibility in front of the public. The company will try to submit its financial reports more quickly to the auditors and be willing to provide information related to the evidence needed by the auditors, so the audit process and audit reports will be more quickly submitted to the company. This allows the company to be able to be on time to submit its audited financial statements to the public. Diliasmara and Nadirsyah (2019) proved that ownership structure affects the timeliness of the submission of financial statements, but different results were stated by Dewi and Sridarta (2019); Janrosi and Prima (2018); Utami and Yennisa (2017).

The larger firm size, the greater total assets owned by the company. A large number of assets can support the company's operational activities. If the company's operational activities generate high income and are accompanied by efficient company expenses, then the profit generated by the company will be even greater, which is good news for investors. If the company can provide information needed by the auditors during the audit process, such as proof of ownership and use of assets, the audit report will be provided more quickly to the company and allow the company to be able to be on time to submit its audited financial statements to the public. Pradipta and Suryono (2017), and Ferdina and Wirama (2017) proved that company size affects the timeliness of financial statement submission.

Auditor switching is a break in the former auditor's relationship with the company and then the appointment of a new auditor to replace the old one (Sastrawan and Badera, 2018). Auditor switching in this study referred to the change of auditors, both mandatory and voluntary. The mandatory AP \& KAP changes are changes within a certain period of time in accordance with the regulations set by the government, while voluntary changes occur due to client and/or KAP initiatives due to several factors (Mukhtar, Sebrina and Mulyani, 2019). When the company does not change auditors, the auditors do not take long to understand the characteristics of the client's business and the systems used in the company. To obtain information about company transactions, auditors also do not have to communicate with previous auditors so they do not need to spend a lot of time carrying out the audit 
process. Auditors can submit their audit reports more quickly so that companies can immediately submit their audited financial statements to the public. Sastrawan and Badera (2018) show that auditor turnover has a negative effect on the delivery of financial statements. Tillah, Sebrina and Mulyani (2019); Ningsih (2016) stated that auditor change does not effect on the timeliness of submitting financial statements.

This study aims to obtain empirical evidence regarding the effect of debt to equity ratio (DER), audit delay, public ownership structure, firm size, and also auditor switching towards the timeliness of financial statement submission on consumer goods sector companies listed on the IDX year 2017-2019.

\section{LITERATURE REVIEW AND HYPOTHESIS DEVELOPMENT}

Literature Review

Compliance Theory

Martinez, dkk. (2015) in Susandya (2018) stated that compliance theory is based on expectations of rewards and efforts to avoid penalties (sanctions) that may be imposed. The imposition of sanctions is considered as the only way to achieve legal compliance, in the event of rejection or incapacity. In other words, compliance theory focuses more on legal solutions (Sitorus and Andayani, 2019). Compliance with the timeliness of submitting annual financial statements in Indonesia has been regulated in the Surat Keputusan Bapepam No. KEP346/BL/2011 attachment No. X.K.2 (Otoritas Jasa Keuangan, 2011) and Peraturan Bursa Efek Indonesia (2004) No. III.1.6.2. If the company violates these regulations, it will be subject to sanctions in accordance with the Exchange Rule Number I-H provision II.6.

Regarding the submission of financial reports to the public, a positive response is obtained by the company by immediately submitting its financial reports (instrument perspective). As for the normative perspective, individuals tend to report in a timely manner because it is considered a normative commitment through morality. According to Werksman, dkk. (2014) in Susandya (2018), compliance theory can encourage companies to submit financial reports on time so that financial reports will be very useful for financial statements users.

\section{Financial Statements}

Based on Qualitative Characteristics of Useful Financial Information states, there are 2 (two) qualitative characteristics information: fundamental and enhancing. Fundamental qualitative characteristics include relevance and precise representation (Ikatan Akuntan Indonesia, 2018). Meanwhile, the qualitative characteristics of the enhancer include comparability, verifiability, timeliness, and understanding. In the stock market and Otoritas Jasa Keuangan Regulation (2011) KEP346/BL/2011 No. X.K.2, the Financial Services Authority (OJK) states that public companies listed are required to submit Periodic Financial Reports to OJK at least 2 (two) copies, one of which is in original form, and accompanied by a report in electronic copy (soft copy). The printed original documents must be signed by the board of directors and/or officials appointed by the directors meanwhile the electronic documents are in the form of .pdf files (portable document format) which is a conversion of the printed documents.

\section{Auditing}

Auditing is a process of collecting (accumulating) and evaluating evidence about information to determine and report the level of conformity (collision) between information and the specified criteria or regulations (Arens, Elder and Beasley, 2017). At the end of the examination, KAP will provide an audit report consisting of an opinion and audited financial statements. The opinion sheet is the responsibility of the public accountant, where the public accountant gives his opinion on the fairness of the financial statements prepared by management (Agoes, 2017).

\section{Timeliness of Financial Statements Submission}

The timeliness of financial statements submission is the quality of information available when needed or the quality of good information in terms of time can be measured based on the date of submission of the audited annual financial statements to the OJK (Sastrawan and Badera, 2018). Timeliness does not guarantee relevance, but relevance is not possible without timeliness. Therefore, timeliness is important in the publication of financial reports (Sanjaya and Wirawati, 2016). Public companies are required to publish their financial statements no later than the end of the third month after the date of the annual report, except for reports in 2019, where an extension of the annual financial report submission deadline is extended by 2 months from the initial deadline which should be amended no later than March 31 to May 31. If a public company or issuer violates these provisions, it will be subject to sanctions and fines based on 
Peraturan I-H Ketentuan II.6 by the Indonesia Stock xchange (Bursa Efek Indonesia, 2004).

\section{Hypothesis Development}

Debt to Equity Ratio (DER)

Debt to Equity Ratio (DER) in this research is used as proxy of leverage ratio. DER measures the level of debt utilization against the total equity owned by the company (Pradipta and Suryono, 2017). The results of research conducted by Janrosi and Prima (2018); Pradipta and Suryono (2017); Ferdina and Wirama (2017); Sanjaya and Wirawati (2016) show that the debt to equity ratio (DER) affects the timeliness of financial statements submission negatively.

Ha1: Debt to Equity Ratio (DER) has a negative effect on the timeliness of financial statements submission.

\section{Audit Delay}

Audit delay is the time span required by a public accountant to complete the auditing process and present his opinion on the annual financial statements. Audit delay plays an important role in influencing the speed of announcing financial statements to the public (Soares and Amin, 2016). Audit delay can directly affect the timeliness of information received and affect decision-making and control capabilities. The length of time to complete the audit is one of the most important determinants of timeliness (Givoly and Palmon, 1982 in Mawardi, 2017). The results of research conducted by Sujarwo (2019); Rahmayanti (2016); Soares and Amin (2016); Ningsih (2016) show that audit delay affects the timeliness of financial statements submission.

$\mathrm{Ha}_{2}$ : Audit delay has a negative effect on the timeliness of financial statements submission.

\section{Public Ownership Structure}

Public ownership structure is the proportion of shares owned by the public to company shares. The definition of public here is an individual or institution that owns shares below 5\%, who are outside management and have no special relationship with the company. Stocks that are owned by the public indicate that the company has high credibility to the community in providing dividends (Hamdani, Yuliandari dan Budiono, 2017). The results of research conducted by Dili-asmara and Nadirsyah (2019); Elviani (2017); Sanjaya and Wirawati (2016) show that ownership structure affects the timeli- ness of financial statements submission positively.

Ha3: Public ownership structure has a positive effect on the timeliness of financial statements submission.

Firm Size

According to OJK Regulation Number 4, the classification of companies or firm size is divided into: (1) small-scale company, if it has total assets not more than IDR 50,000,000,000; (2) medium-scale company, if it has total assets between IDR $50,000,000,000$ to IDR 250,000,000,000; (3) largescale company, if it has total assets exceeding IDR $250,000,000,000$. The results of research conducted by Pradipta and Suryono (2017); Utami and Yennisa (2017); Ferdina and Wirama (2017); Sanjaya and Wirawati (2016) show that firm size affects the timeliness of financial statement submission positively.

Ha: Firm size has a positive effect on the timeliness of financial statements submission.

\section{Auditor Switching}

Auditor switching can occur due to mandatory regulations and voluntarily (based on management decisions). Mandatory switching are changing within a certain period of time in accordance with regulations set by the government, while voluntary switching occurs due to client initiatives and/or public accountant firms due to several factors (Mukhtar, Sebrina and Mulyani, 2019). Auditing Standards Statement No. 16 provides guidance on the communication between the predecessor auditor and the successor auditor when the auditor changes. Matters for inquiry must include information that may relate to management's integrity, disagreements with management regarding the application of accounting principles, audit procedures or similar significant matters, communications with the audit committee or other parties with equal authority and responsibility regarding fraud, elements of legal violations by clients, and issues related to internal control, and the upstream auditor's understanding of the reasons for auditor replacement (Ikatan Akuntan Publik Indonesia, 2011). The results of research conducted by Sastrawan and Badera (2018) show that auditor switching affects the timeliness of financial statement submission negatively.

Ha5: Auditor switching has a negative effect on the timeliness of financial statements submission. 
Research Model

The research model is presented in Figure 1.

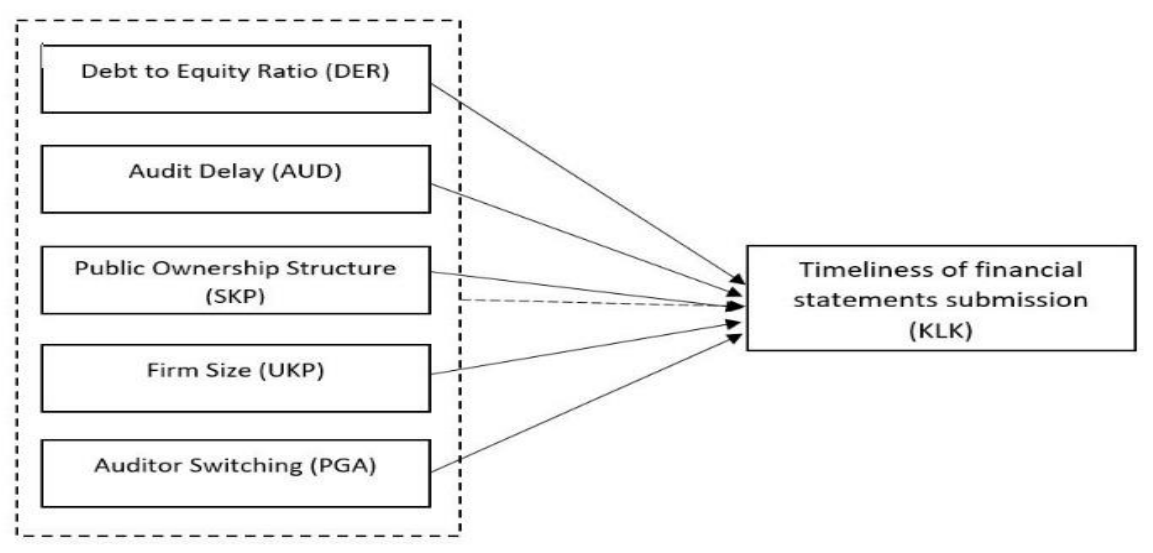

Figure 1. Research Model

\section{RESEARCH METHODS}

\section{Research Variable}

\section{Dependent Variable}

The timeliness of financial statements submission as referred to in this study is the availability of audited financial statement information for decision makers at the latest at the end of the third month after the date of the financial statements so that it can influence their decisions. The timeliness of submitting financial statements is calculated using dummy variables with the following categories: (1) Code 1, if the company publishes its financial statements on time. Financial reports for the 2017 and 2018 periods are said to be on time if the financial reports are published no later than March 31. As for the financial statements for the 2019 period, it is said to be on time if the financial reports are published no later than May 31, 2020; (2) Code 0, if the company is not on time.

\section{Independent Variable}

1. Debt to Equity Ratio (DER)

Debt to Equity Ratio (DER) is used to measure the level of debt to total equity owned by the company. According to Soares and Amin (2016), DER can be formulated as follows:

Debt to Equity Ratio $=\frac{\text { Total liabilities }}{\text { Total equity }}$

\section{Audit Delay}

Audit delay is time span required by a public accountant to complete the auditing process and present his opinion on the annual financial report (Soares and Amin, 2016). According to Rahmayanti (2016), audit delay is measured based on the range of days of closing books (December 31) to the time the audit report/opinion is issued by the Public Accounting Firm (KAP).

3. Public Ownership Structure

Public ownership structure is the proportion of shares owned by the public to company shares (Hamdani, Yuliandari and Budiono, 2017). The definition of public here is an individual or institution that owns shares below $5 \%(<5 \%)$ who are outside management and have no special relationship with the company. The structure of public ownership can be formulated as follows (Hamdani. Yuliandari and Budiono, 2017):

Public Ownership Structure $=\frac{\text { Public Shareholding }}{\text { Total Shares }}$

4. Firm Size

Firm size can be formulated as follows (Pradipta and Suryono, 2017):

$$
\text { Firm Size }=\ln \text { Total Asset }
$$

5. Auditor Switching

This variable is measured by a dummy variable. In this study, the categories of auditor switching were: (1) Code $1=$ if the company underwent auditor switching during the 2017-2019 period; (2) Code $0=$ if the company has not undergone auditor switching during the 2017-2019 period.

\section{Data Sampling}

Sample was selected using purposive sampling method, with criteria: 
1. Consumer goods companies listed on the Indonesia Stock Exchange (IDX) consecutively during the 2017-2019 period.

2. Has a closing date as of December 31, issuing financial reports that have been audited by an independent auditor, and using rupiah currency during the 2017-2019 period.

3. Disclose the number of public shareholdings below 5\% during the 2017-2019 period.

4. Disclose the date of submission of financial statements for the 2017-2019 period.

5. Do not have negative equity balance during the 2017-2019 period.

\section{Data Analysis Technique}

In this study, the test was carried out with the logistic regression with the regression model used is as follows:

$$
\begin{aligned}
& \ln \frac{K L K}{1-K L K}=\alpha+\beta 1 D E R+\beta 2 A U D+\beta 3 S K P+ \\
& \beta 4 U K P+\beta 5 P G A+e
\end{aligned}
$$

\section{RESULTS AND DISCUSSION}

Results

Sampling Results

The final results of the sample are 39 companies with three year observations, so total data used are 117. The sampling results are shown in Table 1.

Table 1. Sampling Results

\begin{tabular}{llc}
\hline No. & \multicolumn{1}{c}{ Criteria } & $\begin{array}{l}\text { Number of } \\
\text { Companies }\end{array}$ \\
\hline 1. & $\begin{array}{l}\text { Consumer goods companies } \\
\text { listed on the Indonesia Stock } \\
\text { Exchange (IDX) consecutively } \\
\text { during the 2017-2019 period }\end{array}$ & \\
\hline $2 . \quad \begin{array}{l}\text { Has a closing date as of Decem- } \\
\text { ber 31, issuing financial reports } \\
\text { that have been audited by an } \\
\text { independent auditor, and using } \\
\text { rupiah currency during the } \\
\text { 2017-2019 period. }\end{array}$ \\
\hline $3 . \quad \begin{array}{l}\text { Disclose the number of public } \\
\text { shareholdings below 5\% during } \\
\text { the 2017-2019 period }\end{array}$ \\
\hline $4 . \quad \begin{array}{l}\text { Disclose the date of submission } \\
\text { of financial statements for the } \\
\text { 2017-2019 period. }\end{array}$ \\
\hline Do not have negative equity \\
balance during the 2017-2019 \\
period
\end{tabular}

Descriptive Statistics

The following is a table of descriptive statistical results:
Table 2. Descriptive Statistics Test Results

\begin{tabular}{lllllll}
\hline & N & Range & Min. & Max. & Mean & $\begin{array}{l}\text { Std. } \\
\text { Dev. }\end{array}$ \\
\hline X1_DER & 117 & 3.2693 & .0697 & 3.3389 & .784737 & .666 \\
\hline X2_AUD & 117 & 153 & 29 & 182 & 84.17 & 23.585 \\
\hline X3_SKP & 117 & .7683 & .0512 & .8195 & .250134 & .17348 \\
\hline X4_UKP & 117 & 9.0503 & 23.1506 & 32.2010 & 28.260142 & 1.6470 \\
\hline $\begin{array}{l}\text { Valid N } \\
\text { (listwise) }\end{array}$ & 117 & & & & & \\
\hline
\end{tabular}

Based on Table 2, the debt to equity (DER) variable has an average value (mean) $=0.7847$ which indicates that the average sample data uses equity more than debt in corporate funding because the average DER value is less than 1 . Audit delay has mean $=84.17$ days, this shows that the average sample data is on time because based on OJK and Stock Exchange regulations, companies must submit their financial statements no later than the end of the third month after the date of the financial statements. The variable of public ownership structure has mean $=0.2501$ or $25.01 \%$, which means that the average public ownership structure in the sample data is $25.01 \%$. Firm size has mean = 28.2601 or IDR $1,875,961,213,728.76$ which can be concluded that the sample data companies are large-scale companies because the total asset value is more than IDR 250,000,000,000.

Meanwhile, descriptive statistics for PGA and KLK are illustrated by means of a pie chart. The following is a pie chart for auditor switching:

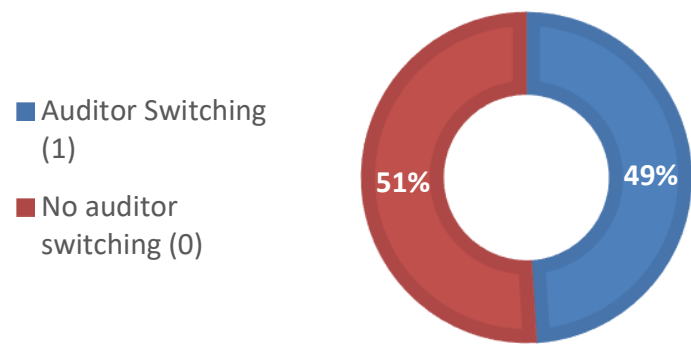

\section{Figure 2. Pie Chart Auditor Switching (PGA)}

Based on Figure 2, there are 57 sample data or $49 \%$ that experienced auditor switching, and the remaining 60 sample data or $51 \%$ did not experience auditor switching.

Based on Figure 3, there are 91 sample data or $78 \%$ submitted their financial reports on time or in accordance with existing regulations. And the remaining 26 sample data or the other $22 \%$ did not submit their financial reports on time. 
- Submit on time (1)

- Submit not on time (0)

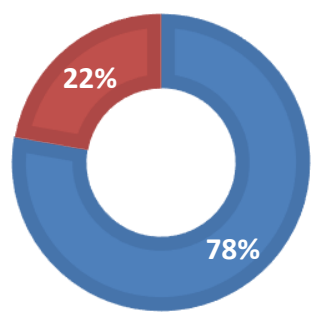

Figure 3. Pie Chart Timeliness of Financial Statements Submission (KLK)

\section{Hypothesis Testing}

Overall Fit Model

Assessing the fit model can be seen from the 2LogL value in Block 0, that is, without variables, only constants are as large as 123.951 and after entering the fifth independent variables value $-2 \log \mathrm{L}$ in Block 1 has decreased to 76.965 or there has been a decrease of 46.986 . To determine whether the decrease is significant or not, it can be compared with the Chi Square table value with df (the difference between the df of the two models). Df with only constants is df $1=n-1=117-1=116$, and df with 5 independent variables is df2 $=\mathrm{n}-\mathrm{k}=117-5=112$, so the difference between the $\mathrm{df}$ of the two models is $\mathrm{df}=\mathrm{df} 1-\mathrm{df} 2=116-112=4$. From the Chi Square table with $\mathrm{df}=4$, we get the number 9.488. This shows that the difference in the reduction of $-2 \log \mathrm{L}$ is greater than the Chi Square table value, which is $46.986>9.488$, so it can be concluded that the difference in reduction of $-2 \log L$ is significant, which means the addition of the five independent variables, namely DER, AUD, SKP, UKP, and PGA into the model improve for the fit model.

\section{Cox E Snell's R Square and Nagelkerke's R Square}

Table 3 shows the value of Cox \& Snell's R Square $=0.331$ and Nagelkerke's $R$ Square value $=$ 0.506 . This means that the variability of the dependent variable, timeliness of financial statements submission, can be explained by the variability of the independent variables: Debt to Equity Ratio, Audit Delay, Public Ownership Structure, Firm Size, and Auditor Switching amounted to 50.6\%, while $49.4 \%$ other is explained by other variables not used in this study.

Table 3. Cox \& Snell's R Square and Nagelkerke's R Square Test Result

\begin{tabular}{cccc}
\hline Step & $\begin{array}{c}-2 \text { Log } \\
\text { likelihood }\end{array}$ & $\begin{array}{c}\text { Cox \& Snell } \\
\text { R Square }\end{array}$ & $\begin{array}{c}\text { Nagelkerke } \\
\text { R Square }\end{array}$ \\
\hline 1 & 76.965 & .331 & .506 \\
\hline
\end{tabular}

Assessing the Feasibility of a Regression Model

Table 4 shows that the value of the Hosmer \& Lemeshow's Test is 1.786 with a significance value of 0.987 whose value is above 0.05 . So it can be concluded that the model is fit and acceptable. Here are the results of Hosmer \& Lemeshow's test:

Table 4. Hosmer \& Lemeshow's Test Result

\begin{tabular}{cccc}
\hline Step & Chi-Square & df & Sig. \\
\hline 1 & 1.786 & 8 & .987 \\
\hline
\end{tabular}

\section{Classification Table}

The classification table calculates correct and incorrect values, which are described as follows:

Table 5. Overall Classification Rate Result

\begin{tabular}{cccc}
\hline \multicolumn{4}{c}{ Predicted } \\
\hline Observed & $\begin{array}{c}\text { Not on } \\
\text { time }\end{array}$ & On time & \% Correct \\
\hline Not on time & 14 & 12 & 53.8 \\
\hline On time & 5 & 86 & 94.5 \\
\hline $\begin{array}{c}\text { Overall Per- } \\
\text { centage }\end{array}$ & & 85.5 \\
\hline
\end{tabular}

The classification table calculates the correct and incorrect values. According to predictions, 26 companies are not on time in submitting their financial statements, but the results of the observations in Table 4 show that 14 companies are not on time in submitting their financial statements, while 12 other companies should not be on time but turned out to be on time in submitting the financial statements. Thus, the classification accuracy is $53.8 \%$. Furthermore, according to predictions, 91 companies submit their financial reports on time, but the results of the observations in Table 4 show that there are 86 companies that submit their financial reports on time, while the other 5 companies should be on time but they are not. The classification accuracy is $94.5 \%$. Thus, the overall classification accuracy is $85.5 \%$.

\section{Parameter Estimation and Interpretation}

Estimated parameters and their interpretations are used to test the effect of each independent variable on the dependent variable. The following are the results of the Variable in the Equation test:

Table 6. Variable in the Equation Test Result

\begin{tabular}{ccccccc}
\hline & B & S.E. & Wald & df & Sig. & Exp(B) \\
\hline X1_DER & -1.309 & .430 & 9.265 & 1 & .002 & .270 \\
\hline X2_AUD & -.038 & .013 & 9.105 & 1 & .003 & .962 \\
\hline X3_SKP & -5.418 & 1.717 & 9.958 & 1 & .002 & .004 \\
\hline X4_UKP & .411 & .195 & 4.454 & 1 & .035 & 1.509 \\
\hline X5_PGA & .776 & .654 & 1.407 & 1 & .235 & 2.173 \\
\hline Constant & -4.521 & 5.411 & .698 & 1 & .403 & .011 \\
\hline
\end{tabular}


Table 6 shows that the Debt to Equity Ratio (DER) variable has a B value of -1.309 with a significance value of 0.002 which means it is smaller than 0.05 ( $\mathrm{\alpha}$ ). So it can be concluded that $\mathrm{Ha}_{1}$ is accepted, meaning that the debt to equity ratio (DER) has a significant negative effect on the timeliness of financial statements submission. The results of this study are in line with research conducted by Janrosi and Prima (2018); Pradipta and Suryono (2017); Ferdina and Wirama (2017) which indicate that the debt to equity ratio (DER) affects the timeliness of financial statements submission. But not in line with research conducted by Dilasmara and Nadirsyah (2019); Elviani (2017); Utami and Yennisa (2017).

Mean value of DER (0.78) indicates that the use of debt as a financial source is low so that financial risks and the possibility of default will be lower. This is good news for investors as well as creditors so that the company is on time in submitting its financial statements to auditors. Low credit risk also encourages company to provide information related to the evidence of corporate financial risk required by the auditors faster and the auditors complete the audit process and report more quickly, so that companies can be on time in submitting their audited financial statements to the public.

The Audit Delay (AUD) variable has a B value of -0.038 with a significance value of 0.003 which means it is smaller than 0.05 (a). So it can be concluded that $\mathrm{Ha}_{2}$ is accepted because audit delay has a significant negative effect on the timeliness of financial report submission. The results of this study support research results conducted by Sujarwo (2019); Rahmayanti (2016); Soares and Amin (2016); Ningsih (2016) but do not support the research conducted by Astuty (2016).

Mean value of Audit Delay (84 days) indicates that the majority of companies provide information related to the evidence needed by the auditors during the audit process so that it can speed up the audit process carried out by the auditor. This makes the time needed for companies to get their audited financial reports faster, so the company faster (on time) in submitting their audited financial statements to the public.

The variable of Public Ownership Structure (SKP) has a $B$ value of -5.418 with a significant value of 0.002 which means it is smaller than 0.05 ( $\alpha)$. So it can be concluded that $\mathrm{Ha}_{3}$ is rejected, meaning that the public ownership structure has a significant negative effect on the timeliness of financial statements submission. The results of this study are in line with research conducted by Diliasmara and Nadirsyah (2019); Elviani (2017); Sanjaya and Wirawati (2016). However, it contradicts the results of research conducted by Dewi and Sridarta (2019); Janrosi and Prima (2018); Utami and Yennisa (2017).

The firm size variable (UKP) has a B value of 0.411 with a significance value of 0.035 , which is smaller than 0.05 (a). So it can be concluded that $\mathrm{Ha}_{4}$ is accepted, meaning that firm size has a significant positive effect on the timeliness of financial statements submission. The results of this study are in line with research conducted by Pradipta and Suryono (2017); Utami and Yennisa (2017); Ferdina and Wirama (2017); Sanjaya and Wirawati (2016) but contrary to the results of a study conducted by Tifanny, Rahayu and Yustien (2020).

The auditor switching variable (PGA) has a B value of 0.776 with a significance value of 0.235 , which is greater than $0.05(\alpha)$. So it can be concluded that $\mathrm{Ha}_{5}$ is rejected, meaning that auditor switching does not have a negative effect on the timeliness of financial statements. Companies that change auditors are not always late in submitting their financial reports. Of the 117 sample data, there were 60 sample data $(51 \%)$ that did not change auditors and there were 57 sample data $(49 \%)$ that made auditor switching. Of the 60 sample data that did not change auditors, $48(80 \%)$ of them were sample data that were on time in submitting their financial reports, and $12(20 \%)$ were sample data that were late in submitting their financial reports. And of the 57 sample data that made auditor switching, $43(75.44 \%)$ of them were sample data that were on time in submitting their financial reports. Of the 43 sample data that were on time, there were $42(97.67 \%)$ sample data that made voluntary auditor switching, and 1 (2.33\%) other sample data made mandatory auditor switching. It can be concluded, although the majority of sample data do voluntary auditor switching, auditors will try to be on time in completing the audit process and audit reports so that the company can be on time in submitting audited financial reports to the public. Because, if the auditor is late in submitting the audit report, this will have an impact on the reputation of the auditor and public accountant firm (KAP). PT Chitose Internasional Tbk (CINT) made auditor changes in the 2017 and 2018 period and in 2019 did not change auditors, but was still on time in submitting its financial reports during the 20172019 period. In the 2017-2019 period, the company trusted Rodl \& Partner as KAP which was responsible for auditing its financial statements. However, 
the public accountant (AP) who was responsible for the 2017 period was Fitradewa Teramihardja, while in the 2018-2019 period the AP who was in charge was Nursal. In 2017, the date of CINT's audit report was March 20, 2018 and submitted its financial report was on March 27, 2018. In the 2018 period, CINT's audit report date was March 15, 2019 and submitted its financial report on March 27, 2019. And in 2019, CINT's audit report date is March 23, 2020 and submits the financial report on March 30, 2020. The results of this study are in line with research conducted by Tillah, Sebrina and Mulyani(2019); Desyana (2019); Ningsih (2016). However, it is different from the results of research conducted by Sastrawan and Badera (2018).

Based on Table 6, the logistic regression equation can be stated as follows:

$$
\begin{gathered}
\ln \frac{K L K}{1-K L K}=-4.521-1.309 D E R-0.038 A U D- \\
5.418 S K P+0.411 U K P+0.776 P G A \ldots \ldots(5)
\end{gathered}
$$

The relationship between odds and the independent variable can be explained as follows: The DER variable has a regression coefficient value $=$ 1,309 which shows that, if AUD, SKP, UKP, and PGA are constant, then the odds of KLK will decrease by a factor of $0.270\left(\mathrm{e}^{-1.309}\right)$ for every one-unit increment of the DER variable. The AUD variable has a regression coefficient value $=-0.038$ which indicates that, if DER, SKP, UKP, and PGA are constant, then the odds of KLK will decrease by a factor of $0.962\left(\mathrm{e}^{-0.038}\right)$ for every increase of one AUD unit.

The SKP variable has a regression coefficient value $=-5,418$ which indicates that if DER, AUD, UKP, and PGA are constant, then the odds of KLK will decrease by a factor of $0.004\left(\mathrm{e}^{-5.418}\right)$ for every increase of one SKP unit. The difference in direction between the hypothesis and SKP's research results occurs because even though the public ownership of a company is small, the company will still be on time in submitting its financial reports. Of the 117 sample data, there are 72 sample data $(61.54 \%)$ that have a public ownership structure below the average of this study, $14.17 \%$. And from 72 sample data that have ownership structure below the average of this study, there are $62(86.11 \%)$ sample data that are on time in sub-mitting their financial reports.

Regulation No. I-V regarding Special Provisions for Listing Shares on the Acceleration Board stated that the minimum number of public ownership structures is 7.5\%(Bursa Efek Indonesia, 2018). The fulfillment of these regulations resulted in alt- hough the ma-jority of the percentage of observation public ownership structures was below the overall average, companies still reported their financial reports on time. For example, PT Akasha Wira International Tbk (ADES) has a percentage of public ownership below the average of this study, namely $8.48 \%$, but can still submit its financial reports on time during the study period (2017-2019 period). In the 2017 period, ADES submitted its financial statements on March $28^{\text {th }}, 2018$. For the 2018 period, ADES submitted its financial statements on March 27th, 2019. Meanwhile, in the 2019 period, ADES reported its financial statements on May 27th, 2020.

The UKP variable has a regression coefficient value $=0.411$ which indicates that if DER, AUD, SKP, and PGA are constant, then the odds of KLK will increase by a factor of $1.509\left(\mathrm{e}^{0.411}\right)$ for every increase of one UKP unit. The PGA variable has a regression coefficient value of 0.776 which indicates that if DER, AUD, SKP, and UKP are constant, then the odds of KLK will decrease by a factor of 2.173 $\left(\mathrm{e}^{-0.776}\right)$ for every increase of one PGA unit. The difference in direction between the hypothesis and the results of the PGA study occurs because even though the company changes auditors, the auditors will try to be on time in the audit process and also the audit reports so that the company can still be on time in delivering its financial statements. Like PT Delta Djakarta Tbk (DLTA), which changed auditors during the study period, however, they were still able to be on time in submitting their financial reports. In the 2017 and 2018 period, DLTA trusted Deloitte as the public accountant firm (KAP) which was responsible for auditing its financial statements. However, the responsible partner/public accountant (AP) was different, in 2017, the AP in charge was Parlindungan Siahaan while in 2018 it was Henri Arifian. As for the 2019 period, DLTA trusted Crowe as the KAP which was responsible for auditing its financial statements and the responsible AP was Mulyadi. In the 2017 period, DLTA's audit report date was March 26 $6^{\text {th }}, 2018$, and DLTA submitted its financial statements on March 28th, 2018. Meanwhile, in 2018, DLTA's audit report date was March 28 ${ }^{\text {th }}, 2019$, and DLTA submitted its financial statements on March 29th, 2019. In 2019, DLTA's audit report date is March $20^{\text {th }}, 2020$. DLTA submits its financial report on April 27th 2020.

To determine the effect of the independent variable simultaneously on the dependent variable, the Omnibus Test of Model Coefficients was used. The following are the results of the Omnibus Test: 
Table 7. Omnibus Test Result

\begin{tabular}{ccccc} 
& & Chi-Square & df & Sig. \\
\hline Step 1 & Step & 46.987 & 5 & .000 \\
\hline & Block & 46.987 & 5 & .000 \\
\hline & Model & 46.987 & 5 & .000
\end{tabular}

Table 7 shows that the Chi Square result is 46.987. With $\mathrm{df}=$ the number of independent variables $=5$, the Chi Square table value is 11.070. The independent variable can simultaneously influence the dependent variable if the calculated Chi Square value is greater than the Chi Square table $(46,987>$ $11,070)$ and the significance value is below 0.05 $(0.000<0.05)$. This shows that the independent variables, there are Debt to Equity Ratio, audit delay, public ownership structure, firm size, and auditor switching simultaneously affect the dependent variable, that is the timeliness of financial statements submission.

\section{CONCLUSION}

The conclusions obtained from this research are Debt to equity ratio (DER) has significant negative effect on the timeliness of financial statements submission (Ha1 accepted). Audit delay has significant negative effect on the timeliness of financial statements submission (Ha2 accepted). Public ownership structure has significant negative effect on the timeliness of financial statements submission (Ha3 rejected). Firm size has a significant positive effect on the timeliness of financial statements submission (Ha4 accepted.). Auditor switching does not have a negative effect on the timeliness of the submission of the financial statements (Ha5 rejected).

The limitation of this study is research period is only for 3 years, the 2017-2019 periods, so results cannot be generalized. Therefore, suggestions that can be addressed to further research is using research period of more than 3 years so that provide more accurate and generalizable research results.

\section{REFERENCES}

Agoes, S. (2017). Auditing: Petunjuk Praktis Pemeriksaan Akuntan oleh Akuntan Publik (Edisi ke-5). Jakarta: Salemba Empat.

Arens, A. A., Elder, R. J., and Beasley, M. S. (2017). Auditing and Assurance Services. Essex: Pearson Education Limited.

Astuty, W. (2016). Profitabilitas, Ukuran Perusahaan, Reputasi Kantor Akuntan Publik, Audit Report Lag Terhadap Ketepatan Waktu Pelaporan. Prosiding. Forum Manajemen Indonesia ke-8: Palu.

Bursa Efek Indonesia. (2004). Peraturan Nomor I-H
Tentang Sanksi. Didapat dari: https:/ / www.idx.co.id/media/1328/19.pdf, 20 Januari 2021, pukul 17:50 WIB.

Bursa Efek Indonesia. (2018). Peraturan Nomor I-V tentang Ketentuan Khusus Pencatatan Saham di Papan Akseleras. Didapat dari https:/ / www.idx.co.id/media/2579/konsepperaturan-i-v-papan-akselerasi-rmr.pdf, 08 Januari 2021, pukul 10:20 WIB.

Bursa Efek Indonesia. (2020). Surat Keputusan Direksi PT Bursa Efek Indonesia perihal Relaksasi Batas Waktu Penyampaian Laporan Keuangan dan Laporan Tahunan. Didapat dari https://idx.co.id/media/8436/sk_relaksasi_b atas_waktu_penyampaian_laporan_keuangan _dan_laporan_tahunan.pdf, 10 Januari 2021, pukul 14:15 WIB.

Desyana, G. (2019). Pengaruh Debt to Equity Ratio, Profitabilitas, Kualitas Auditor, dan Pergantian Auditor terhadap Ketepatan Waktu Pelaporan Keuangan pada Perusahaan Manufaktur yang Terdaftar di BEI. Jurnal Audit dan Akuntansi Fakultas Ekonomi dan Bisnis Universitas Tanjungpura, 8(1), 1-18.

Dewi, N. P. S. K. and Sridarta, Y. M. (2019). Laba Akuntansi, Arus Kas Operasi, Struktur Kepemilikan, dan Opini Audit Terhadap Ketepatan Waktu Publikasi Laporan Keuangan. Media Akuntansi, 31(1), 44-53.

Diliasmara, D. A., and Nadirsyah. (2019). Pengaruh Profitabilitas, Likuiditas, Financial Leverage, dan Struktur Kepemilikan Terhadap Ketepatan Waktu Pelaporan Keuangan pada Perusahaan Manufaktur yang Terdaftar di Bursa Efek Indonesia pada Tahun 2013-2015. Jurnal Ilmiah Mahasiswa Ekonomi Indonesia (JIMEKA), 4(2), 304-316.

Elviani, S. (2017). Faktor-faktor Berpengaruh Bagi Ketepatan Waktu Pelaporan Keuangan Perusahaan Manufaktur di Bursa Efek Indonesia. Jurnal Riset Akuntansi Multiparadigma, 4(3), 1-10.

Ferdina, N. W. A., and Wirama, D. G. (2017). Pengaruh Profitabilitas, Leverage, Likuiditas Dan Ukuran Perusahaan Pada Ketepatwaktuan Laporan Keuangan. E-Jurnal Akuntansi, 19(3), 2293-2318.

Forddanta, D. H., and Rafie, B. T. (2018). Dewan komisaris AISA satu suara menolak tanda tangan laporan tahunan. Didapat dari https://investasi.kontan.co.id/news/dewankomisaris-aisa-satu-suara-menolak-tandatangan-laporan-tahunan, 10 Maret 2020, pukul 09:30 WIB 
Hamdani, S. P., Yuliandari, W. S., and Budiono, E. (2017). Kepemilikan Saham Publik dan Return On Assets terhadap Pengungkapan Corporate Social Responsibility. Jurnal Riset Akuntansi Kontemporer, 9(1), 47-54.

Ikatan Akuntan Indonesia. (2018). Standar Akuntansi Keuangan. Jakarta: Ikatan Akuntan Indonesia.

Institut Akuntan Publik Indonesia. (2011). Standar Profesional Akuntan Publik. Jakarta: Salemba Empat.

Janrosi, V. S., and Prima, A. P. (2018). Analisis Faktor-Faktor yang Mempengaruhi Ketepatan Waktu Pelaporan Keuangan. Jurnal Politeknik Caltex Riau, 11(1), 61-68.

Mawardi, R. (2017). The Effect Of Internal and External Factors to Audit Delay and Timeliness. Jurnal Riset Akuntansi dan Bisnis Airlangga, 2(1), 165-180.

Mukhtar, I. S., Sebrina, N., and Mulyani, E. (2019). Pengaruh Kinerja Perusahaan, Komite Audit, dan Pergantian Auditor Eksternal Terhadap Ketepatwaktuan Pelaporan Keuangan. Jurnal Eksplorasi Akuntansi, 1(2), 605-626.

Ningsih, W. Y. (2016). Faktor-Faktor yang Berpengaruh terhadap Rentang Waktu Ketepatan Penyampaian Laporan Keuangan ke Publik Studi di Bursa Efek Indonesia 20052009.. AkMen Jurnal Ilmiah, 13(2), 447-454.

Otoritas Jasa Keuangan. (2011). Penyampaian Laporan Keuangan Berkala Emiten Atau Perusahaan Publik. Didapat dari https://www.ojk.go.id/Files/regulasi/pasarmodal/bapepam-pm/emitenpp/pelaporan/X.K.2.pdf., 20 Desember 2020, pukul 11.30 WIB.

Pradipta, D. N., and Suryono, B. (2017). Analisis Faktor-Faktor yang Mempengaruhi Ketepatan Waktu Pelaporan Keuangan. Jurnal Ilmu dan Riset Akuntansi, 6(3), 1200-1215.

Rahmayanti, D. (2016). Audit Delay, Profitability, dan Kontribusinya terhadap Ketepatan Waktu. ADVANCE, 3(1), 12-26.

Saleh, T. (2019). BEI Suspensi 10 Emiten 'Nakal' Sekaligus, Kenapa sih? Didapat dari https://www.cnbcindonesia.com/market/201 90730170226-17-88653/bei-suspensi-10-emitennakal-sekaligus-kenapa-sih, 10 Maret 2020, pukul 09:00 WIB

Sanjaya, I. M. D. M., and Wirawati, N. G. P. (2016). Analisis Faktor-Faktor Yang Mempengaruhi Ketepatan Waktu Pelaporan Keuangan pada Perusahaan Manufaktur yang Terdaftar di BEI.
E-Jurnal Akuntansi, 15(1), 17-26.

Saragih, H. P. (2019). Kisah Hostile Take Over di Tiga Pilar \& Hasil Investigasi EY. Didapat dari https://www.cnbcindonesia.com/market/201 90327104727-17-63136/kisah-hostile-take-overdi-tiga-pilar-hasil-investigasi-ey, 10 Maret 2020, pukul 09:20 WIB.

Sastrawan, A. R. K. and Badera, I. D. (2018). Anteseden Ketepatwaktuan Publikasi Laporan Keuangan dengan Financial Destress sebagai Pemoderasian. E-Jurnal Akuntansi, 22(2), 914943.

Sitorus, B. E. E. J., and Andayani. (2019). Faktorfaktor yang Mempengaruhi Ketepatan Waktu Pelaporan Keuangan Perusahaan Pertambangan. Jurnal Ilmu dan Riset Akuntansi, 8(11), 1-19.

Soares, M., and Amin, M. N. (2016). Analisis Faktor-Faktor yang Mempengaruhi Timeliness of Financial Reporting dengan Reputasi Auditor sebagai Variabel Moderasi atas Profitabilitas, Leverage, dan Umur Perusahaan. Jurnal Magister Akuntansi Trisakti (e-Journal), 3(2), 121-146.

Sujarwo. (2019). Pengaruh Audit Delay, Reputasi dan Kompleksitas Operasi Terhadap Timeliness Pelaporan Keuangan Perusahaan Pertambangan Tahun 2012-2016. Scientific Journal Of Reflection: Economic, Accounting, Management and Business, 2(3), 331-340.

Susandya, A. A. P. G. B. A. (2018). The Effect of Cooperative's Characteristic on Financial Reporting Timeliness. Sriwijaya International Journal of Dynamic Economics and Business, 2(4), 269-292.

Thertina, M. R. (2020). Laporan Keuangan Tiga Pilar Disclaimer, Sahamnya Masih Disuspensi BEI. Didapat dari https://katadata.co.id/marthathertina/finansi al/5e9a495be9e31/laporan-keuangan-tigapilar-disclaimer-sahamnya-masih-disuspensibei, 20 Maret 2020, 10.30 WIB.

Tifanny, Rahayu, S. and Yustien, R. (2020). Determinan ketepatan waktu pelaporan keuangan. Imanensi, 5(1), 53-60.

Tillah, M., Sebrina, N., and Mulyani, E. (2019). Pengaruh Kinerja Perusahaan, Komite Audit, Pergantian Auditor Eksternal Terhadap Ketepatwaktuan Pelaporan Keuangan. Jurnal Eksplorasi Akuntansi, 1(3), 1530-1540.

Utami, D., and Yennisa. (2017). Faktor-Faktor Mempengaruhi Ketepatan Waktu Pelaporan Keuangan. Akuntansi Dewantara, 1(1), 31-38. 